\title{
PENGARUH DOSIS PUPUK KANDANG AYAM YANG DIFERMENTASI EM4 DAN KONSENTRASI BIOURINE SAPI TERHADAP PERTUMBUHAN DAN HASIL BAYAM JEPANG (Spinacia oleracea L.)
}

\author{
Putu Suwardike*, Putu Sri Wahyuni*, I Made Artika* \\ email: putu.suwardike@unipas.ac.id
}

*Fakultas Pertanian Universitas Panji Sakti, Singaraja

\begin{abstract}
The study aimed at finding out the EM4 fermented chicken manure dosage, the concentration of cow biourine, and the interaction between the two which gave the best growth and yield of Japanese spinach were carried out in Candikuning Village, Baturiti District, Tabanan Regency, at altitude of 1,500 m asl. The trial lasted 45 days, starting from Mid April - May 2019, using a Randomized Group Design (RBD), consisting of two factors. The first factor is the chicken manure dose EM-4 fermented (A), with 4 levels, namely: (AO) without chicken manure (control), (A1) chicken manure dose of 10 tons.ha-1 or 480 grams / plot, (A2) chicken manure dose of 20 ton.ha-1 or 960 gram / plot, and (A3) chicken manure dose of 30 ton.ha-1 or $1440 \mathrm{gram} /$ plot. The second factor is the concentration of bovine biourine (B), with 4 levels, namely: (BO) without bovine biourine (control), (B1) concentration of $100 \mathrm{ml} . \mathrm{l}-1$ bovine biourine solution or 10\%, (B2) $200 \mathrm{ml}$ bovine biourine concentration. l-1 solution or 20\%, (B3) $300 \mathrm{ml} .1-1$ concentration of beef biourine solution or 30\%. The results of the analysis showed that the EM4 fermented chicken manure had a significant effect on almost all variables observed, except plant height per plant aged 17 days and oven dry weight of leaves per plant. The EM4 fermented chicken manure dose of 20 ton.ha-1 gave the highest total wet weight per plant, which was $228.74 \mathrm{~g}$ and the highest total oven dry weight per plant, ie $115.37 \mathrm{~g}$. The optimal dose of fermented chicken manure EM-4 is 18.40 ton.ha-1 with a total oven dry weight per plant maximum $=135.21 \mathrm{~g}$. The concentration of $200 \mathrm{ml} . \mathrm{l}-1$ biourine cattle gave the highest total wet weight per plant, which was $238.01 \mathrm{~g}$ and the highest total oven dry weight, which was $121.51 \mathrm{~g}$. The optimal concentration of beef biourine is $176.69 \mathrm{ml} . \mathrm{l}-1$ with a total oven dry weight per plant maximum = $135.44 \mathrm{~g}$. The interaction between EM4 fermented chicken manure doses and cattle biourine concentration only significantly affected the number of leaves per plant aged 45 days.
\end{abstract}

Keywords. Chicken manure, Biourine cow, Japanese spinach

Abstrak. Penelitian yang betujuan untuk mengetahui dosis pupuk kandang ayam difermentasi EM4, konsentrasi biourine sapi, dan interaksi antara keduanya yang memberikan pertumbuhan dan hasil bayam Jepang terbaik telah dilakukan di Desa Candikuning, Kecamatan Baturiti, Kabupaten Tabanan, pada ketinggian tempat $1.500 \mathrm{~m}$ dpl. Percobaan berlangsung selama 45 hari, mulai dari Pertengahan April - Mei 2019, menggunaan Rancangan Acak Kelompok (RAK), terdiri dari dua faktor. Faktor pertama dosis pupuk kandang kandang ayam difermentasi EM-4 (A), dengan 4 taraf yaitu : $\left(\mathrm{A}_{0}\right)$ tanpa pupuk kandang ayam (kontrol), $\left(\mathrm{A}_{1}\right)$ pupuk kandang ayam dosis 10 ton.ha ${ }^{-1}$ atau 480 gram/petak, $\left(\mathrm{A}_{2}\right)$ pupuk kandang ayam dosis 20 ton.ha ${ }^{-1}$ atau 960 gram/petak, dan $\left(\mathrm{A}_{3}\right)$ pupuk kandang ayam dosis 30 ton.ha ${ }^{-1}$ atau 1440 gram/petak. Faktor kedua kensentrasi biourine sapi (B), dengan 4 taraf yaitu : $\left(\mathrm{B}_{0}\right)$ tanpa biourine sapi (kontrol), $\left(\mathrm{B}_{1}\right)$ konsentrasi biourine sapi $100 \mathrm{mll}^{1^{-1}}$ larutan atau $10 \%,\left(\mathrm{~B}_{2}\right)$ konsentrasi biourine sapi $200 \mathrm{ml}^{l^{-1}}$ larutan atau 20\%, $\left(\mathrm{B}_{3}\right)$ konsentrasi biourine sapi $300 \mathrm{ml}^{-1} \mathrm{I}^{-1}$ larutan atau 30\%. Hasil analisis ragam menunjukan dosis pupuk kandang ayam yang difermentasi EM4 berpengaruh nyata sampai sangat nyata terhadap hampir semua variabel yang diamati, kecuali tinggi tanaman per tanaman umur 17 hst dan berat kering oven daun per tanaman. Dosis pupuk kandang ayam yang difermentasi EM4 20 ton.ha $^{-1}$ memberikan berat basah total per tanaman tertinggi, yaitu 228,74 g dan berat kering oven total per tanaman tertinggi, yaitu $115,37 \mathrm{~g}$. Dosis optimal pupuk kandang ayam yang difermentasi EM-4 yaitu18,40 ton.ha ${ }^{-1}$ dengan berat kering oven total per tanaman maksimum $=135,21 \mathrm{~g}$. Konsentrasi biourine sapi $200 \mathrm{ml.}^{-1}$ larutan memberikan berat basah total per tanaman tertinggi, yaitu 238,01 g dan berat kering oven total tertinggi, yaitu $121,51 \mathrm{~g}$. Konsentrasi optimal biourine sapi yaitu $176,69 \mathrm{ml}^{-1} \mathrm{l}^{-1}$ dengan berat kering oven total per tanaman maksimum $=135,44 \mathrm{~g}$. Interaksi antara dosis pupuk kandang ayam yang difermentasi EM4 dan konsentrasi biourine sapi hanya berpengaruh nyata terhadap jumlah daun per tanaman umur 45 hst.

Kata kunci: Pupuk kandang ayam, Biourine sapi, Bayam jepang

\section{PENDAHULUAN}

(Spinacia oleracea L.) merupakan salah satu jenis sayuran yang umur panennya singkat dan cukup digemari oleh masyarakat. Salah satu jenis bayam tersebut adalah bayam Jepang. Tanaman ini memiliki beberapa keunggulan dibanding jenis bayam lainnya karena mengandung lemak jenuh lebih rendah, yaitu $0,10 \mathrm{~g}$ per $100 \mathrm{~g}$ daun; gula lebih rendah, yaitu $0,40 \mathrm{~g}$ per $100 \mathrm{~g}$; dan memiliki nutrisi lebih tinggi, seperti Natrium mencapai $79 \mathrm{mg}$, Kalium mencapai $558 \mathrm{mg}$, Vitamin A sekitar 9.377 IU, dan Vitamin C sekitar 28,10 mg dibanding bayam lokal 
(Fatimah, 2009; Suwardi, 2011; Anonim, 2019). Kondisi ini menyebabkan bayam Jepang memiliki nilai ekonomis cukup tinggi. Harga di tingkat petani mencapai Rp. 15.000,/kg hingga Rp. 20.000,-/kg, dan harga di supermarket dapat mencapai Rp. 50.000,-/kg.

Meskipun bayam Jepang memiliki nilai ekonomis cukup tinggi, namun karena merupakan jenis tanaman baru yang dikembangkan di Indonesia dan daerah adaptasinya terbatas pada dataran tinggi dengan ketinggian > $700 \mathrm{~m} \mathrm{dpl}$, maka luas areal tanam dan produksinya masih sangat terbatas. Salah satu upaya untuk meningkatkan produksi tanaman bayam Jepang melalui teknik budidaya adalah melalui pemupukan yang bermaksud meningkatkan produktivitas tanah dengan penyediaan nutrisi tanaman (Rukmana, 2005).

Bayam Jepang dapat dibudidayakan secara intensif dengan menggunakan berbagai input, seperti pupuk anorganik dan pestisida sintetik secara maksimal. Namun dapat pula dibudidaya dengan teknologi sederhana, menggunakan input yang lebih ramah lingkungan. Input yang lebih ramah lingkungan dimaksud dapat berupa pupuk organik, pupuk hayati, pestisida organik atau pestisida nabati, dan berbagai jenis input yang degradabel lainnya. Budidaya bayam Jepang secara organik cukup menjanjikan keuntungan bagi petani karena biaya produksi menjadi lebih rendah dan produk yang dihasilkan dapat memasuki pasar-pasar tertentu yang lebih menyukai produk organik. Pengembangan bayam Jepang secara organik sesuai dengan perkembangan masyarakat saat ini yang lebih peduli dengan kesehatan dan sejalan dengan slogan back to nature di era abad 21 dan modern seperti sekarang ini. Menurut Sutanto (2012), penggunaan pupuk anorganik dapat meningkatkan produktivitas tanah dalam jangka pendek, tetapi dapat merusak struktur tanah dan menurunkan produktivitas tanaman dalam jangka panjang.

Pupuk organik merupakan pupuk yang berperan meningkatkan aktivitas biologi, kimia, dan fisik tanah sehingga tanah menjadi subur dan baik untuk pertumbuhan tanaman. Saat ini sebagian besar petani masih tergantung pada pupuk anorganik karena mengandung beberapa unsur hara dalam jumlah yang banyak,padahal jikapupuk anorganik digunakan secara terus-menerus akan menimbulkan dampak negatif terhadap kondisi tanah (Indriani, 2004).

Pupuk organik ada beberapa jenis, berbentuk padat maupun cair. Pupuk organik padat antara lain berupa pupuk kandang. Sedangkan pupuk organik cair antara lain berupa biourine. Pupuk kandang juga cukup beragam jenisnya, salah satunya adalah pupuk kandang ayam. Demikian halnya dengan biourine, salah satu jenis biourine yang cukup dikenal dikalangan petani adalah biourine sapi. Pupuk organik yang berasal dari ternak hewan antara lain untuk menambahkan unsur hara dalam tanah, menambahkan humus atau bahan organik tanah, memperbaiki kehidupan jasad renik tanah dan meningkatkan kemampuan tanah mengikat air (Setyamidjaja, 1986). Pupuk kandangayam akan memperbaiki sifat fisik, kimia dan biologi tanah. Kondisi ini akan menunjang budidaya sayuran bayam Jepang yang memerlukan tanah gembur, subur dan mengandung bahan organik, sehingga akar dapat tumbuh dengan baik (Subhan, 1989).

Pemberian pupuk kandang ayam pada tanaman bayam Jepang dapat dilakukan setelah pupuk mengalami dekomposisi atau difermentasi dengan baik atau telah mengalami penyimpanan selama $2-3$ bulan, dengan dosis 10 - 30 ton.ha $^{-1}$ (Wibowo, 1995). Hasil penelitian Punuindoong dkk. (2017) menunjukan bahwa pemberian pupuk kandang ayam dengan dosis 20 ton.ha ${ }^{-1}$, memberikan pengaruh terbaik terhadap pertumbuhan dan hasil produksi. Ini terlihat dari tingginya berat kering oven per tanaman yaitu $5,79 \mathrm{~g}$ atau meningkat $58,55 \%$ bila dibandingkan dengan perlakuan tanpa pupuk kandang ayam yaitu2,40 g. Sari dkk. (2016) menunjukan bahwa pemberian pupuk kandang ayam dengan dosis 20 ton.ha ${ }^{-1}$, menghasilkan berat kering oven per tanaman kubis yaitu72,18 g atau meningkat $87,48 \%$ bila dibandingkan dengan perlakuan tanpapupuk kandang ayam yaitu 38,50 g. Selanjutnya hasil penelitian Habibi dkk. 
(2015) menunjukan bahwa pemberian pupuk kompos dengan dosis 20 ton.ha ${ }^{-1}$, menghasilkan berat basah berangkasan per tanaman sawi yaitu169,52 g atau meningkat $47,79 \%$ bila dibandingkan dengan perlakuan tanpa pupuk kompos yaitu114,70 g.

Sebagaimana telah disebutkan pada alenia diatas, salah satu jenis biourine adalah biourine sapi. Kelebihan biourine sapi adalah unsur hara yang terdapat didalamnya lebih mudah diserap tanaman (Murbandono, 1990). Pemberian biourine sapi juga harus memperhatikan dosis yang diaplikasikan terhadap tanaman. Kelebihan dosis biourine dapat mengakibatkan timbulnya gejala kelayuan pada tanaman (Rahmidan Jumiati, 2007).

Biourine sapi merupakan urine sapiyang sebelumnya telah melalui proses fermentasi dengan melibatkan peran mikroorganisme. Fermentasi merupakan aktivitas mikroorganisme baik aerob maupun anaerob yang mampu mengubah atau mentransformasikan senyawa kimia ke subtrat organik. Fermentasi dapat terjadi karena adanya aktivitas mikroorganisme (Rahman dkk., 1989).

Aplikasi biourine sapi berbeda dengan pupuk organik padat. Biourine sapi diaplikasikan pada tanaman setelah tanaman tumbuh, karena pada saat masa pertumbuhan dan perkembang biakan tanaman banyak membutuh kannutrisi (Sutari, 2010). Keunggulan biourine sapi sebagai sumber hara bagi tanaman telah dibuktikan dalam percobaan lapang. Beberapa hasil penelitian menunjukan penggunaan biourine sapi berdampak positif terhadap pertumbuhan dan hasil tanaman.

Hasil penelitian Rizki, dkk. (2014) menunjukan bahwa penggunaan biourine sapi dengan konsentrasi $200 \mathrm{ml}^{-1} \mathrm{l}^{-1}$ larutanatau $20 \%$ rata-rata memberikan hasil jumlah daun sawi hijau tertinggi yaitu 12,65 helai atau secara nyata lebih tinggi $68,67 \%$, jika dibandingkan dengan tanpa konsentrasi biourine sapi menghasilkan jumlah daun terendah yaitu7,50 helai.

\section{BAHAN DAN METODE}

Percobaan ini dilaksanakan di Desa Candikuning, Kecamatan Baturiti, Kabupaten Tabanan, dengan ketinggian tempat $1.500 \mathrm{~m}$ di atas permukaan laut. Percobaan ini berlangsung selama 45 hari mulai dari pertengahan April - Mei 2019.

Bahan-bahan yang digunakan dalam percobaan ini meliputi: benih Bayam Jepang hibrida Arlite, pupuk kandang ayam yang sudah difermentasi dengan EM4, biourine sapi, mulsa, plastik transparan. Sedangkan alat-alat yang digunakan meliputi: cangkul, penggaris, meteran, gelas ukur, handsprayer, timbangan digital, kawat, pisau, ember plastik, label, alat tulis kantor dan kamera.

Percobaan ini menggunakan percobaan faktorial dengan Rancangan Acak Kelompok (RAK). Perlakuan yang dicoba terdiri dari dua faktor yaitu Faktor pertama pupuk kandang kandang ayam difermentasi EM4 (A), dengan 4 taraf yaitu :

$\mathrm{A}_{0} \quad$ : tanpa pupuk kandang ayam (kontrol)

$\mathrm{A}_{1} \quad$ : pupuk kandang ayam dosis 10 ton.ha ${ }^{-1}$ atau 480 gram/petak

$\mathrm{A}_{2} \quad$ : pupuk kandang ayam dosis 20 ton.ha ${ }^{-1}$ atau 960 gram/petak

$\mathrm{A}_{3} \quad$ : pupuk kandang ayam dosis 30 ton.ha ${ }^{-1}$ atau 1440 gram/petak

Faktor kedua kensentrasi biourine sapi (B), dengan 4 taraf yaitu :

$\mathrm{B}_{0} \quad: \quad$ tanpa biourine sapi (kontrol)

$\mathrm{B}_{1} \quad$ : konsentrasi biourine sapi 100 ml..$^{-1}$ larutan atau $10 \%$

$\mathrm{B}_{2} \quad$ : konsentrasi biourine sapi 200 ml..$^{-1}$ larutan atau $20 \%$

$\mathrm{B}_{3} \quad$ : konsentrasi biourine sapi 300 ml..$^{-1}$ larutan atau $30 \%$

Seluruh perlakuan dikombinasikan sehingga keseluruhan terdapat 16 kombinasi perlakuan. Masing-masing kombinasi perlakuan diulang 3 kali, satu petak perlakuan terdapat 9 tanaman, sehingga seluruhnya berjumlah 432 tanaman. variabel yang diamati dalam percobaan ini adalah: 1) tinggi tanaman per tanaman $(\mathrm{cm})$; 2) jumlah daun per tanaman (helai); 3) berat basah daun per tanaman (g); 4) berat basah akar per tanaman (g); 5) berat basah total per tanaman $(\mathrm{kg}) ; 6)$ berat kering oven daun per tanaman $(\mathrm{g}) ; 7$ ) berat kering 
oven akar per tanaman $(\mathrm{g})$; 8) berat kering oven total per tanaman $(\mathrm{g})$

Data hasil penelitian ini dianalisis secara statistika sesuai dengan rancangan yang digunakan, yaitu Rancangan Acak Kelompok (RAK). Apabila antara perlakuan menunjukan perbedaan yang nyata atau sangat nyata, maka dilanjutkan dengan uji BNT pada taraf $5 \%$. Apabila pengaruh interaksi berpengaruh nyata atau sangat nyata dilanjutkan dengan uji Duncan Multiple Range Test pada taraf 5\% (Hanafiah, 2001).

\section{HASIL}

Perlakuan konsentrasi biourine sapi berpengaruh sangat nyata $(\mathrm{p}<0,01)$ terhadap tinggi tanaman per tanaman umur 45 hst, 38 hst, jumlah daun per tanaman umur 45 hst, 38 hst dan berat kering oven akar per tanaman. Perlakuan konsentrasi biourine sapi berpengaruh nyata $(p<0,05)$ tehadap tinggi tanaman umur 31 hst, jumlah daun per tanaman umur $31 \mathrm{hst}, 17 \mathrm{hst}$, berat basah daun per tanaman, berat basah total per tanaman, berat kering oven daun per tanaman, dan berat kering oven total per tanaman. Namun berpengaruh tidak nyata $(p \geq 0,05)$ terhadap variabel lainnya.

Tabel 1. Signifikansi pengaruh perlakuan dosis pupuk kandang ayam yang difermentasi EM4 dan konsentrasi biourine sapi tehadap pertumbuhan dan hasil bayam jepang organik

\begin{tabular}{|c|c|c|c|c|}
\hline \multirow{2}{*}{ No. } & \multirow{2}{*}{ Variabel } & \multicolumn{3}{|c|}{ Perlakuan } \\
\hline & & A & B & $\mathrm{AB}$ \\
\hline \multirow[t]{6}{*}{1} & Tinggi tanaman per tanaman (cm) & & & \\
\hline & Pada umur 17 hst & NS & NS & NS \\
\hline & Pada umur 24 hst & $*$ & NS & NS \\
\hline & Pada umur 31 hst & $*$ & $*$ & NS \\
\hline & Pada umur 38 hst & $* *$ & $* *$ & NS \\
\hline & Pada umur 45 hst & ** & $* *$ & NS \\
\hline \multirow[t]{6}{*}{2.} & Jumlah daun per tanaman (helai) & & & \\
\hline & Pada umur 17 hst & $* *$ & $*$ & NS \\
\hline & Pada umur 24 hst & $* *$ & NS & NS \\
\hline & Pada umur 31 hst & * & $*$ & NS \\
\hline & Pada umur 38 hst & $* *$ & $* *$ & NS \\
\hline & Pada umur 45 hst & $* *$ & $* *$ & $*$ \\
\hline 3. & Berat basah daun per tanaman $(\mathrm{g})$ & $*$ & $*$ & NS \\
\hline 4. & Berat basah akar per tanaman (g) & $* *$ & NS & NS \\
\hline 5. & Berat basah total per tanaman $(\mathrm{g})$ & * & $*$ & NS \\
\hline 6. & Berat kering oven daun per tanaman (g) & NS & $*$ & NS \\
\hline 7. & Berat kering oven akar per tanaman (g) & $* *$ & $* *$ & NS \\
\hline 8. & Berat kering oven total per tanaman (g) & $*$ & $*$ & NS \\
\hline
\end{tabular}

Keterangan: A : pupuk ayam yang difermentasi EM4; B : konsentrasi biourine sapi ; $\mathrm{AB}$ : interaksi pupuk ayam yang difermentasi EM4dan konsentrasi biourine sapi ; NS : berpengaruh tidak nyata $(\mathrm{p} \geq 0,05) ; *$ : berpengaruh nyata $(\mathrm{p}<0,05) ; * *$ : berpengaruh sangat nyata $(\mathrm{p}<0,01)$.

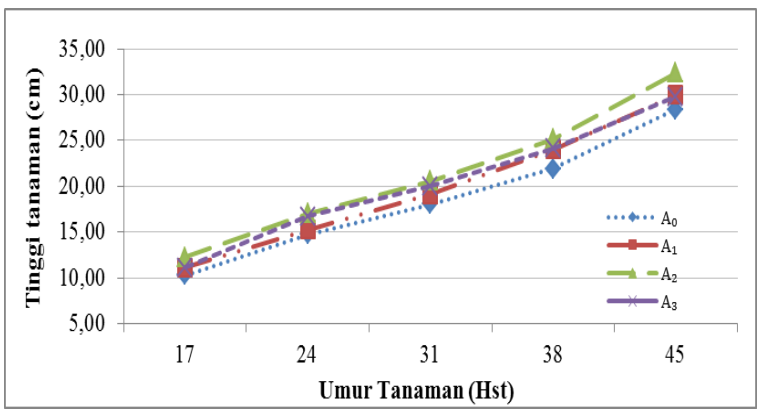

Gambar 1. Grafik pertumbuhan tinggi tanaman per tanaman karena pengaruh dosis pupuk kandang ayam yang difermentasi EM4

Tabel 2. Pengaruh perlakuan dosispupuk kandang ayam yang difermentasi EM4 dan konsentrasi biourine sapi terhadap tinggi tanaman per tanaman 


\begin{tabular}{|c|c|c|c|c|c|}
\hline \multirow{2}{*}{ Perlakuan } & \multicolumn{5}{|c|}{ Tingigitanaman per tanaman (cm) pada umur (hst) } \\
\hline & 17 & 24 & 31 & 38 & 45 \\
\hline \multicolumn{6}{|l|}{ Dosis Pupuk Kandang Ayam(A) } \\
\hline Kontrol $\left(A_{0}\right)$ & 10,30 & $14,73 \mathrm{a}$ & $18,05 \mathrm{a}$ & $21,92 \mathrm{a}$ & $28,39 \mathrm{a}$ \\
\hline Dosis 10 ton.ha- ${ }^{-}$atau 480 gram/petak $\left(\mathrm{A}_{1}\right)$ & 11,10 & $15,21 \mathrm{a}$ & $19,14 \mathrm{a}$ & 24,016 & $29,99 \mathrm{a}$ \\
\hline Dosis 20 ton.ha-1 atau 960 gram/petak $\left(\mathrm{A}_{2}\right)$ & 12,26 & 17,006 & $20,54 b$ & 25,176 & $32,39 \mathrm{~b}$ \\
\hline Dosis 30 ton.ha-1 atau 1440 gram/petak $\left(\mathrm{A}_{3}\right)$ & 11,10 & $16,67 b$ & $19,98 \mathrm{a}$ & $24,16 b$ & $29,79 \mathrm{a}$ \\
\hline BNT $5 \%$ & NS & 1,56 & 1,70 & 1,44 & 2,03 \\
\hline \multicolumn{6}{|l|}{ Konsentrasi Biourine (B) } \\
\hline Kontrol $\left(B_{0}\right)$ & 10,30 & 14,61 & $18,19 \mathrm{a}$ & $22,33 \mathrm{a}$ & $28,00 \mathrm{a}$ \\
\hline Konsentrasibiourine sapi $100 \mathrm{mll} .1-1$ air atau 10\% $\left(\mathrm{B}_{1}\right)$ & 11,10 & 15,96 & $18,88 \mathrm{a}$ & $23,32 \mathrm{a}$ & $29,60 \mathrm{a}$ \\
\hline Konsentrasibiourine sapi $200 \mathrm{mll} .1-1$ air atau $20 \%\left(\mathrm{~B}_{2}\right)$ & 12,01 & 16,75 & $20,84 b$ & $26,08 b$ & $32,70 \mathrm{~b}$ \\
\hline Konsentrasi biourine sapi $300 \mathrm{mll}-1-1$ air atau $30 \%\left(\mathrm{~B}_{3}\right)$ & 11,35 & 16,29 & $19,81 \mathrm{a}$ & $23,52 \mathrm{a}$ & $30,26 \mathrm{a}$ \\
\hline BNT $5 \%$ & NS & NS & 1,70 & 1,44 & 2,03 \\
\hline
\end{tabular}

Keterangan: Angka-angka yang diikuti oleh huruf yang sama pada perlakuan dan variabel yang sama menunjukan perbedaan yang tidak nyata pada uji BNT 0,05

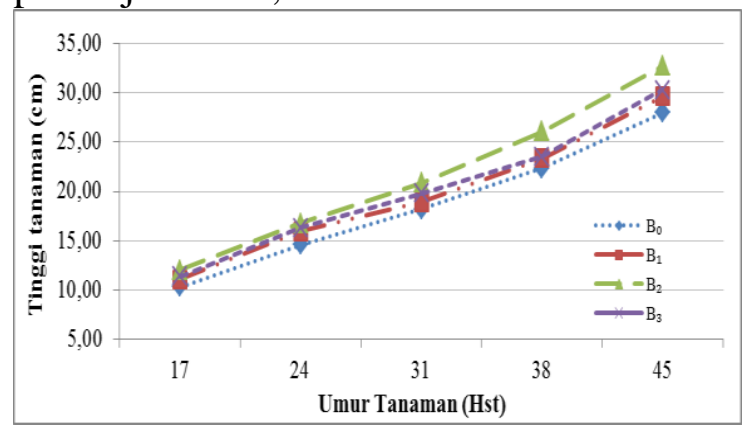

Gambar 2. Grafik pertumbuhan tinggi tanaman per tanaman karena pengaruh konsentrasi biourine sapi

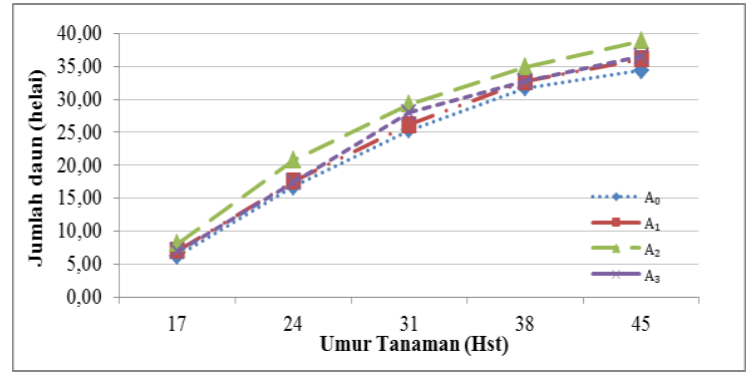

Gambar 3. Grafik pertumbuhan jumlah daun per tanaman karena pengaruh dosis pupuk kandang ayam yang difermentasi EM4

Tabel 3. Pengaruh Perlakuan Dosis Pupuk Kandang Ayam yang Difermentasi EM4dan Konsentrasi Biourine Sapi terhadap Jumlah Daun Per tanaman

\begin{tabular}{|c|c|c|c|c|c|}
\hline \multirow{2}{*}{ Perlakuan } & \multicolumn{5}{|c|}{ Jumlah daun per tanaman (helai) pada umur (hst) } \\
\hline & 17 & 24 & 31 & 38 & 45 \\
\hline \multicolumn{6}{|l|}{ Dosis Pupuk Kandang Ayam (A) } \\
\hline Kontrol $\left(\mathrm{A}_{0}\right)$ & $6,20 \mathrm{a}$ & $16,76 \mathrm{a}$ & $25,31 \mathrm{a}$ & $31,72 \mathrm{a}$ & $34,41 \mathrm{a}$ \\
\hline Dosis 10 ton.ha- ${ }^{-1}$ atau 480 gram/petak $\left(\mathrm{A}_{1}\right)$ & $7,09 \mathrm{a}$ & $17,56 \mathrm{a}$ & $26,16 \mathrm{a}$ & $32,70 \mathrm{a}$ & $36,12 \mathrm{a}$ \\
\hline Dosis 20 ton.ha-1 atau 960 gram/petak $\left(\mathrm{A}_{2}\right)$ & $8,11 \mathrm{~b}$ & $20,77 \mathrm{~b}$ & $29,32 \mathrm{~b}$ & $34,92 b$ & $38,87 \mathrm{~b}$ \\
\hline Dosis 30 ton.ha-1 atau 1440 gram/petak $\left(\mathrm{A}_{3}\right)$ & $6,91 \mathrm{a}$ & $17,45 \mathrm{a}$ & $27,99 \mathrm{a}$ & $32,74 \mathrm{a}$ & $36,53 \mathrm{a}$ \\
\hline BNT 5\% & 1,28 & NS & 2,09 & 1,57 & 2,66 \\
\hline \multicolumn{6}{|l|}{ Konsentrasi Biourine (B) } \\
\hline Kontrol $\left(\mathrm{B}_{0}\right)$ & $6,01 \mathrm{a}$ & $15,74 \mathrm{a}$ & $24,29 \mathrm{a}$ & $30,00 \mathrm{a}$ & $32,33 a$ \\
\hline Konsentrasi biourine sapi 100 ml.1-1 air atau 10\% ( $\left.\mathrm{B}_{1}\right)$ & $6,51 \mathrm{a}$ & $17,01 b$ & $26,25 \mathrm{a}$ & $32,51 \mathrm{~b}$ & $37,26 \mathrm{~b}$ \\
\hline Konsentrasi biourine sapi $200 \mathrm{mll} .1-1$ air atau 20\% $\left(\mathrm{B}_{2}\right)$ & $8,41 \mathrm{c}$ & $21,25 \mathrm{c}$ & $30,04 \mathrm{c}$ & $35,59 \mathrm{c}$ & $38,95 c$ \\
\hline Konsentrasi biourine sapi $300 \mathrm{mll} .1-1$ air atau 30\% $\left(\mathrm{B}_{3}\right)$ & $7,38 \mathrm{~b}$ & $18,55 \mathrm{~b}$ & $28,19 \mathrm{~b}$ & $33,97 \mathrm{~b}$ & $37,40 \mathrm{~b}$ \\
\hline BNT 5\% & 1,28 & 3,10 & 2,09 & 1,57 & 2,66 \\
\hline
\end{tabular}

Keterangan: Angka-angka yang diikuti oleh huruf yang sama pada perlakuan dan variabel yang sama menunjukan perbedaan yang tidak nyata pada uji BNT 0,05

Tabel 4.Kombinasi antara dosis pupuk kandang ayam yang difermentasi EM4 dan konsentrasi biourine sapi terhadap jumlah daun per tanaman

\begin{tabular}{|c|c|c|c|c|l|}
\hline PLK & $\mathrm{B}_{0}$ & $\mathrm{~B}_{1}$ & $\mathrm{~B}_{2}$ & $\mathrm{~B}_{3}$ & Rerata A \\
\hline $\mathrm{A}_{0}$ & $26,37 \mathrm{a}$ & $33,32 \mathrm{~b}$ & $33,08 \mathrm{~b}$ & $34,10 \mathrm{~b}$ & $\mathbf{3 0 , 0 0} \mathbf{b}$ \\
\hline $\mathrm{A}_{1}$ & $30,32 \mathrm{~b}$ & $31,34 \mathrm{~b}$ & $35,80 \mathrm{c}$ & $33,33 \mathrm{~b}$ & $\mathbf{3 2 , 5 1} \mathbf{b}$ \\
\hline $\mathrm{A}_{2}$ & $33,65 \mathrm{~b}$ & $34,46 \mathrm{~b}$ & $37,10 \mathrm{c}$ & $34,48 \mathrm{~b}$ & $\mathbf{3 5 , 5 9} \mathbf{b}$ \\
\hline $\mathrm{A}_{3}$ & $29,67 \mathrm{a}$ & $30,94 \mathrm{~b}$ & $36,38 \mathrm{c}$ & $33,98 \mathrm{~b}$ & $\mathbf{3 3 , 9 7} \mathbf{b}$ \\
\hline Rerata $\mathbf{B}$ & $\mathbf{3 1 , 7 2} \mathbf{b}$ & $\mathbf{3 2 , 7 0} \mathbf{b}$ & $\mathbf{3 4 , 9 2} \mathbf{b}$ & $\mathbf{3 2 , 7 4} \mathbf{b}$ & \\
\hline
\end{tabular}

Keterangan: Angka-angka dengan huruf yang sama pada perlakuan dan variabel yang sama adalah berbeda tidak nyata pada Uji Jarak Berganda Duncan (DMRT) 0,05

Tabel 5. Pengaruh perlakuan dosispupuk kandang ayam yang difermentasi EM4 dan konsentrasi biourine sapi terhadap berat basah daun per tanaman, berat basah akar per tanaman, berat basah total per tanaman 


\begin{tabular}{|c|c|c|c|}
\hline Perlakuan & $\begin{array}{c}\text { Berat Basah Daun } \\
\text { Per tanaman (g) }\end{array}$ & $\begin{array}{l}\text { Berat Basah Akar } \\
\text { Per tanaman (g) }\end{array}$ & $\begin{array}{c}\text { Berat Basah } \\
\text { Total } \\
\text { Per tanaman }(\mathrm{g})\end{array}$ \\
\hline \multicolumn{4}{|l|}{ Dosis Pupuk Kandang Ayam(A) } \\
\hline $\operatorname{Kontrol}\left(A_{0}\right)$ & $165,62 \mathrm{a}$ & 6,30a & $171,93 \mathrm{a}$ \\
\hline Dosis 10 ton.ha- ${ }^{-1}$ atau 480 gram/petak $\left(A_{1}\right)$ & $193,71 \mathrm{a}$ & $7,34 \mathrm{a}$ & $201,05 b$ \\
\hline Dosis 20 ton.ha-1 atau 960 gram/petak $\left(A_{2}\right)$ & $219,96 b$ & $8,78 b$ & $228,74 \mathrm{~b}$ \\
\hline Dosis 30 ton.ha-1 atau 1440 gram/petak $\left(\mathrm{A}_{3}\right)$ & $191,08 \mathrm{a}$ & $7,39 \mathrm{a}$ & $198,47 \mathrm{~b}$ \\
\hline BNT 5\% & 37,01 & 1,25 & 37,69 \\
\hline \multicolumn{4}{|l|}{ Konsentrasi Biourine (B) } \\
\hline $\operatorname{Kontrol}\left(\mathrm{B}_{0}\right)$ & $167,79 \mathrm{a}$ & 6,78 & $174,57 \mathrm{a}$ \\
\hline Konsentrasi biourine sapi 100 ml.1-1 air atau 10\% ( $\left.\mathrm{B}_{1}\right)$ & $183,11 b$ & 7,23 & $190,34 b$ \\
\hline Konsentrasi biourine sapi $200 \mathrm{mll} .1-1$ air atau 20\% $\left(\mathrm{B}_{2}\right)$ & $229,64 \mathrm{c}$ & 8,37 & $238,01 \mathrm{c}$ \\
\hline Konsentrasi biourine sapi $300 \mathrm{mll}-1-1$ air atau $30 \%\left(\mathrm{~B}_{3}\right)$ & $189,84 \mathrm{~b}$ & 7,43 & $197,27 \mathrm{~b}$ \\
\hline BNT $5 \%$ & 37,01 & NS & 37,69 \\
\hline
\end{tabular}

Keterangan: Angka-angka yang diikuti oleh huruf yang sama pada perlakuan dan variabel yang sama menunjukan perbedaan yang tidak nyata pada uji BNT 0,05

Tabel 6. Pengaruh perlakuan dosispupuk kandang ayam yang difermentasi EM4 dan konsentrasi biourine sapi terhadap berat kering oven daun per tanaman, berat kering oven akar per tanaman, berat kering oven total per tanaman

\begin{tabular}{|c|c|c|c|}
\hline Perlakuan & $\begin{array}{l}\text { Berat Kering } \\
\text { Oven Daun Per } \\
\text { tanaman }(\mathrm{g})\end{array}$ & $\begin{array}{c}\text { Berat Kering } \\
\text { Oven Akar Per } \\
\text { tanaman (g) }\end{array}$ & $\begin{array}{c}\text { Berat Kering } \\
\text { Oven TotalPer } \\
\text { tanaman }(\mathrm{g})\end{array}$ \\
\hline \multicolumn{4}{|l|}{ Dosis Pupuk Kandang Ayam(A) } \\
\hline Kontrol $\left(A_{0}\right)$ & 84,14 & $2,96 \mathrm{a}$ & $87,11 \mathrm{a}$ \\
\hline Dosis 10 ton.ha-1 atau 480 gram/petak $\left(A_{1}\right)$ & 99,27 & $3,67 \mathrm{a}$ & $102,94 b$ \\
\hline Dosis 20 ton.ha-1 atau 960 gram/petak $\left(A_{2}\right)$ & 110,98 & $4,39 \mathrm{~b}$ & $115,37 \mathrm{c}$ \\
\hline Dosis 30 ton.ha-1 atau 1440 gram/petak $\left(A_{3}\right)$ & 96,87 & $3,53 \mathrm{a}$ & $100,40 \mathrm{~b}$ \\
\hline BNT 5\% & NS & 0,62 & 19,01 \\
\hline \multicolumn{4}{|l|}{ Konsentrasi Biourine (B) } \\
\hline Kontrol $\left(\mathrm{B}_{0}\right)$ & $86,06 \mathrm{a}$ & $2,95 \mathrm{a}$ & $89,01 \mathrm{a}$ \\
\hline Konsentrasi biourine sapi $100 \mathrm{mll} .1-1$ air atau $10 \%\left(\mathrm{~B}_{1}\right)$ & $93,05 \mathrm{a}$ & $3,61 \mathrm{a}$ & $96,67 \mathrm{a}$ \\
\hline Konsentrasi biourine sapi $200 \mathrm{mll} .1-1$ air atau 20\% $\left(\mathrm{B}_{2}\right)$ & $117,24 b$ & $4,28 b$ & $121,51 b$ \\
\hline Konsentrasibiourine sapi $300 \mathrm{ml} .1-1$ air atau 30\% $\left(\mathrm{B}_{3}\right)$ & $94,94 a$ & $3,72 \mathrm{a}$ & $98,64 a$ \\
\hline BNT $5 \%$ & 18,75 & 0,62 & 19,01 \\
\hline
\end{tabular}

Keterangan: Angka-angka yang diikuti oleh huruf yang sama pada perlakuan dan variabel yang sama menunjukan perbedaan yang tidak nyata pada uji BNT 0,05

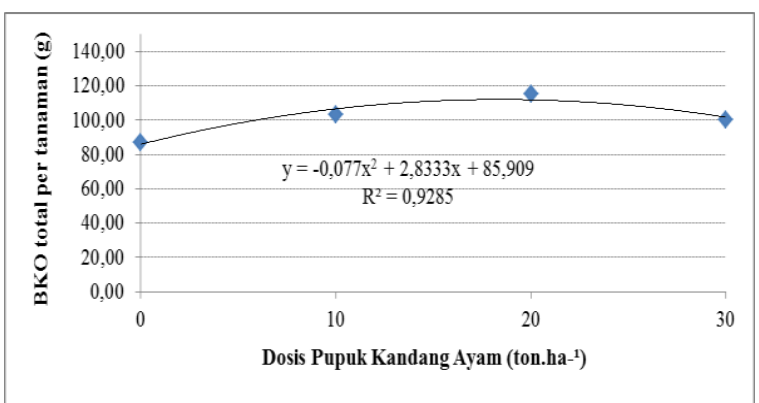

Gambar 3. Grafik bentuk hubungan antara berat kering oven total per tanaman dan dosis pupuk kandang ayam yang difermentasi EM4

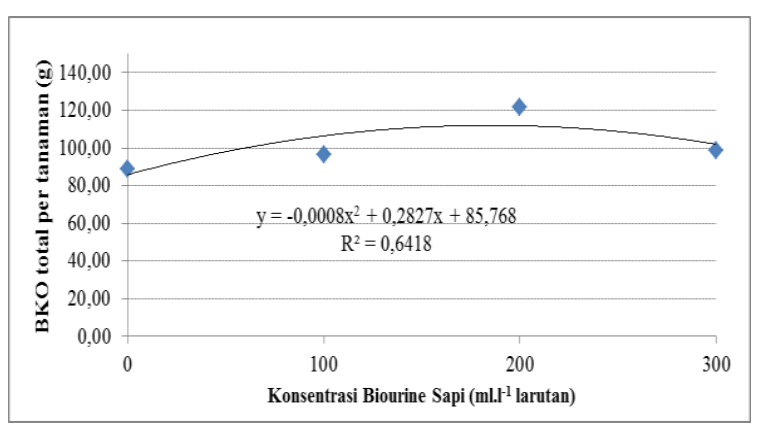

Gambar 4. Grafik bentuk hubungan antara berat kering oven total per tanaman dan konsentrasi biourine sapi

\section{PEMBAHASAN}

Hasil analisis ragam menunjukan bahwa perlakuan dosis pupuk kandang ayam yang difermentasi EM4 (A), konsentrasi biourine sapi (B), dan interaksi antara keduanya menunjukkan pengaruh yang bervariasi terhadap pertumbuhan dan hasil bayam Jepang, sebagaimana tersaji pada Tabel 2.

\section{Perlakuan dosis pupuk kandang ayam yang difermentasi EM4 terhadap pertumbuhan dan hasil bayam Jepang}

Hasil penelitian menunjukan bahwa pemberian pupuk kandang ayam yang difermentasi EM4 dosis 20 ton.ha ${ }^{-1}$ memberikan berat basah total per tanaman tertinggi yaitu 228,74 g; secara nyata lebih tinggi 33,04\% dibandingkan dengan tanpa pupuk kandang ayam yang difermentasi EM4 dengan berat basah total per tanaman terendah yaitu 171,93 g (Tabel 5).

Pemberian pupuk kandang ayam yang difermentasi EM4 dengan dosis 20 ton.ha ${ }^{-1}$ memberikan berat kering oven total per tanaman tertinggi yaitu $115,37 \mathrm{~g}$; secara 
nyata lebih tinggi $32,44 \%$ dibandingkan dengan tanpa pupuk kandang ayam yang difermentasi EM4 yang hanya memberikan berat kering oven total per tanaman terendah yaitu $87,11 \mathrm{~g}$. Hasil analisis regresi hubungan antara dosis pupuk kandang ayam yang difermentasi EM4 (X) dan berat kering oven total per tanaman $(\hat{Y})$ menunjukkan hubungan kuadratik dengan persamaan $\hat{\mathrm{Y}}=-0,077 \mathrm{x}^{2}+$ $2,8333 \mathrm{x}+85,909 ;$ dengan koefisien determinasi $\left(\mathrm{R}^{2}\right)=0,9285$; sehingga diperoleh $\mathrm{X}_{\text {opt }}=18,40$ ton.ha ${ }^{-1}$ dan $\hat{\mathrm{Y}}_{\max }=135,21 \mathrm{~g}$ (Gambar 3). Dari analisis regresi menunjukan hubungan kuadratik, sehingga diketahui dosis optimal pada pemberian pupuk kandang ayam yang difermentasi EM4 pada tanaman bayam Jepang.

Berpengaruhnya pertumbuhan dan hasil produksi pada tanaman bayam Jepang diduga karena fungsi pupuk kandang ayam yang difermentasi EM4 untuk mempertahankan dan memperbaiki sifat-sifat fisik tanah, kimia dan biologis tanah. Sumber utama bahan organik dalam tanah adalah berasal dari pupuk kandang atau kompos baik segar maupun yang sudah lapuk. Pupuk kandang selain mengandung unsur makro seperti $\mathrm{N}, \mathrm{P}, \mathrm{K}, \mathrm{Mg}$, dan $\mathrm{S}$ juga mengandung unsur mikro seperti $\mathrm{Cu}, \mathrm{Fe}$, Mo dan $\mathrm{Zn}$, yang kesemuanya membentuk pupuk, menyediakan unsur-unsur hara bagi pertumbuhan dan perkembangan tanaman.

Pengaruh perlakuan konsentrasi biourine sapi terhadap pertumbuhan dan hasil bayam Jepang

Hasil pengamatan menunjukan pemberian konsentrasi biourine sapi $200 \mathrm{ml} . \mathrm{l}^{-}$ ${ }^{1}$ larutan memperoleh berat basah total per tanaman tertinggi yaitu 238,01 g atau secara nyata $36,34 \%$ dibandingkan dengan tanpa biourine sapi $\left(\mathrm{B}_{0}\right)$ yaitu 174,57 $\mathrm{g}$ (Tabel 5).

Pengaruh pemberian konsentrasi biourine sapi $200 \mathrm{ml} . \mathrm{l}^{-1}$ larutan memperoleh berat berat kering oven total per tanaman tertinggi yaitu $121,51 \mathrm{~g}$ atau secara nyata $36,51 \%$ dibandingkan dengan tanpa biourine sapi yaitu 89,01 g. Hasil analisis regresi hubungan antara konsentrasi biourine sapi (X) dan berat kering oven total per tanaman $(\hat{Y})$ menunjukkan hubungan kuadratik dengan persamaan, yaitu $\hat{Y}=-0,0008 x^{2}+0,2827 x+$ 85,768 dengan koefisien determinasi $\left(\mathrm{R}^{2}\right)=$ 0,6418; sehingga diperoleh $X_{\text {opt }}=176,69 \mathrm{ml}^{-1}$ ${ }^{1}$ larutan dan $\hat{\mathrm{Y}}_{\max }=135,44 \mathrm{~g}($ Gambar 4$)$. Dari analisis regresi menunjukan hubungan kuadratik, sehingga diketahui konsentrasi optimal pada pemberian biourine sapi pada tanaman bayam Jepang.

Hal ini disebabkan karena khasiat utama biourine sapi dapat meningkatkan ketersediaan hara yang cukup dan mudah terserap oleh daun tanaman sehingga akan memacu proses petumbuhan khususnya jumlah daun. Biourine sapi kaya akan unsur hara dan zat pengatur tumbuh seperti sitokinin yang berfungsi mendorong pertumbuhan tunas dan perluasan daun. Kandungan nitrogen pada urine sapi potongsama dengan yang ada pada pupuk SP36, yaitu $36 \%$ nitrogen, atau tidak beda jauh dengan kandungan nitrogen pupuk urea, yakni $45 \%$ (Zein, 2011).

\section{SIMPULAN}

1. Perlakuan dosis pupuk kandang ayam yang difermentasi EM4 berpengaruh nyata sampai sangat nyata terhadap hampir semua variabel yang diamati. Pemberian pupuk kandang ayam yang difermentasi EM4 dosis 20 ton.ha ${ }^{-1}$ memberikan berat kering oven total per tanaman tertinggi yaitu 115,37 g.

2. Dosis optimal pupuk kandang ayam yang difermentasi EM4 adalah 18,40 ton.ha ${ }^{-1}$.

3. Perlakuan konsenterasi biourine sapi berpengaruh nyata sampai sangat nyata terhadap hampir semua variabel yang diamati. Konsentrasi biourine sapi 200 ml. $1^{-1}$ larutan memberikan berat kering oven total per tanaman tertinggi yaitu 4,28 g.

4. Konsentrasi optimal biourine sapi adalah $176,69 \mathrm{ml}^{-1}$.

5. Interaksi antara pupuk kandang ayam yang difermentasi EM4 dan konsentrasi biourine sapi hanya berpengaruh nyata terhadap jumlah daun per tanaman umur 45 hst. 


\section{DAFTAR PUSTAKA}

Agustina L dan Syekhfani. 2002. Hasil Rumusan Lokakarya Nasional Pertanian Organik. Prosiding Lokakarya Nasional Pertanian Organik; 7 - 9 Oktober 2002; Malang, Indonesia. Malang (ID): Universitas Brawijaya Malang.

Afghanaus. 2011. Pupuk Organik Cair. http://afghanaus.com/pupuk-organikcair/. Diakses tanggal 8 Juli 2019

Anonim. 2019. https:// pasarsayuronline. wordpress. com /tag/ nutrisi horenso/ (diakses 24 Januari 2019)

[BSN] Badan Standarisasi Nasional. 2010. Sistem Pangan Organik SNI 016729-

2010. Jakarta (ID): BSN.

Decoteau. D.R., 2000. Vegetative Crop. The Pennsylvania State Univercity, USA.

Habibi, Z., Satriawan, Agusni. 2015. Pengaruh Dosis Pupuk Kompos terhadap Pertumbuhan Tanaman Sawi (Brassica rapa). Program Agroteknologi, Fakultas Pertanian, Universitas Almuslim. Aceh.

Hanafiah, K. A. 2001. Rancangan Percobaan. Raja Grafindo Persada. Jakarta. 182 hal.

Indriani. 2004. Membuat Kompos secara

Kilat. Penebar Swadaya. Jakarta

Indranada, H.K. 1986. Pengelolaan

Kesuburan Tanah. Cetakan Pertama.

P.T. Bina Aksara. Jakarta . 89 hal.

Kartasapoetra, A.G. dan Sutejo M. 1988.

Pupuk dan Cara Pemupukan.

Cetakan pertama. PT. Bina Aksara.

Jakarta. 170 hal.

Lingga, P. 1989. Petunjuk Penggunaan Pupuk. Penebar Swadaya. Jakarta. 163 hal.

Marsono dan Lingga, P. 2001. Petunjuk Penggunaan Pupuk. Penebar Swadaya. Jakarta.

Murbandono. 1990. Membuat Kompos. Penebar Swadaya. Jakarta

Novizan. 2005. Petunjuk Pemupukan yang Efektif. AgroMedia Pustaka. Jakarta.

Pierce, L.C, 1987. Vegetables: Characteristics, Production and
Marketing, John Willey \& Sons. New York.

Pracaya. 2010. Bertanam Sayuran Organik di Kebun, Pot dan Polibag. Jakarta (ID): Penebar Swadaya.

Punuindoong, S., Kumolontang, N.J.W., Kawulusan, I. R. 2017. Respon Tanaman Bayam (Amarathus tricolor L.) terhadap Pemberian berbagai Jenis Pupuk Organik Pada Tanah Marginal. Program Studi Tanah, Fakultas Pertanian, Universitas Sam Ratulangi. Manado.

Prihmantoro, H. 1995. Memupuk Tanaman Sayuran. Penebar Swadaya, Jakarta.

Rahman, A. S., Fardiaz, W. P., Rahaya Suliatari dan Nurwitri, C.C.,1989. Teknologi Pengolahan Susu. Depdikbud Dirjen PT. Pusat Antara Universitas Pangan dan Gisi IPB. Bogor.

Rahmi, A. dan Jumiati. 2007. Pengaruh Konsentrasi dan Waktu Penyemprotan Pupuk Organik Cair Sper ACI terhadap Pertumbuhan dan Hasil Jagung Manis. J. Agritrop.,26(3).,105-109

Rani, D. S. (2016) Pengaruh Biourine Sapi terhadap Pertumbuhan dan Hasil Beberapa Varietas Bawang Merah (Allium ascalonicum L.) pada Lahan Berpasir. Prodi Agroteknologi, Fakultas Pertanian, Universitas PGRI Yogyakarta.

Rinsema, W.T. 1993 . Pupuk dan Cara Pemupukan. Bhratara Karya Aksara. Jakarta. 230 hal.

Rinanto, H., Azizah, N., Santosa, M., (2015) Pengaruh Aplikasi Kombinasi Biourine dengan Pupuk Organik dan Anorganik terhadap pertumbuhan dan Hasil Tanaman Bawang Merah (Allium ascalonicum L.) Jurusan Budidaya Pertanian, Fakultas Pertanian, Universitas Brawijaya, Malang.

Riski, K., Rasyad, A., Murniati. 2014. Pengaruh Pemberian Urin Sapi Yang Difermentasi Terhadap Pertumbuhan Dan Produksi Tanaman Sawi Hijau (Brassica Rafa) 
Rismunandar, 1981. Pengetahuan Dasar Tentang Perabukan. Sinar Baru. Bandung 75 hal.

Rubatzky, V. E. dan M. Yamaguchi, 1998. Sayuran Dunia 2 Prinsip, Produksi, dan Gizi. ITB, Bandung.

Rukmana, R. 2005 Tenik Budidaya Bayam. Kanisius. Yogyakarta

Sari, M. K., Pasigai, A., Wahyudi, I., 2016. Pengaruh Pupuk Kandang Ayam Terhadap Pertumbuhan dan Hasil Tanaman Kubis Bunga (Brassica Oleracea Var. Bathytis L.) Pada Oxic Dystrudepts Lembantongoa. Program Studi Agroteknologi, Fakultas Pertanian, Universitas Tadulako. Palu.

Saragih SE. 2008. Pertanian Organik, Solusi Hidup Harmoni dan Berkelanjutan.

Jakarta (ID): Penebar Swadaya.

Setyamidjaja, D. 1986. Pupuk dan Pemupukan. CV. Sinar Baru. Bandung.

Sidemen, I.N., Raka, I. D. N., Udiyana, P. B., 2016. Pengaruh Jenis Pupuk Organik terhadap Pertumbuhan Tanaman Bayam (Amaranthus Sp) Pada Tanah Tegalan Asal Daerah Kubu, Karangasem. Program Study Agroteknologi, Fakultas Pertanian, Universitas Mahasaraswati. Denpasar.

Smith, A. 2015. Pengaruh Pupuk Daun Gandasil D (daun) dan Ela Sagu terhadap Pertumbuhan dan Produksi Tanaman Selada (Latuca sativa L.) Fakultas Keguruan dan Ilmu Pendidikan, Universitas Darusalam. Ambon.

Sosrosoedirdjo, R.S. dan B. Rifai. 1985. Ilmu Memupuk. Yasaguna. Jakarta. 71 hal.

Subhan. 1989. Pengaruh Macam dan Dosis Pupuk Kandang Terhadap Hasil Kentang (Solanum Tuberosum. L). Skripsi, Universitas Udayana. Denpasar.

Sudiro, A. 2010. Demontrasi Teknologi Pembuatan Pupuk Organik Cair.

Sutari, W, S,. 2010. Uji Kulitas Biourine Hasil Fermentasi Dengan Mikroba Yang Berasal dari Bahan Tanaman
Terhadap Pertumbuhan dan Hasil Tanaman Sawi Hijau (Brassica juncea L.). Tesis Universitas Udayana. Denpasar.

Sutanto, R. 2002. Penerapan Pertanian Organik. Pemasyarakat dan Pengembang. Penerbit: Kanisius, anggota IKAPI Yogyakarta.

Sutedjo, M. 2002. Pupuk dan Cara Pemupukan. Renika Cipta. Jakarta.

Syarief, S. 1989. Kesuburan dan Pemupukan Tanah Pertanian. Pustaka Buana Bandung . 43 Hal.

Tutin, T.G. et al. 1993. Flora Europaea .The Department of Life Sciences, University of Trieste

Warasfarm. 2013. Potensi Urine Sebagai Pupuk Organik Cair. http:// warasfarm. wordpress. Com /2013/01/22/ potensi - urine - sapisebagai - pupuk - organik - cair-poc/. Diakses tanggal 8 Juli 2019.

Wibowo, S. (1995). Budidaya Bawang Merah, Bawang Putih, Bawang Bombai, Penebar Swadaya, Jakarta.

Winaya, D. P. 1985. Pengantar Kesuburan Tanah dan Pupuk. Bagian Ilmu Tanah . Fakultas Pertanian Universitas Udayana . Denpasar. 208 Hal.

Zein, R.A. 2011. Pupuk Cair Organik (Pco). http://www.kampoengternak.or.id. Diakses tanggal 8 Juli 2019. 